\title{
Organizations and Functions for Seed Management in East Asia: Korea, Japan and Taiwan
}

\section{Mitsuyuki Tomiyoshi}

\begin{abstract}
How important are informal seed-saving systems in conserving agrobiodiversity? Mitsuyuki Tomiyoshi probes that question in the East Asian context in this survey and analysis examining the prevalence of community seed banks and other non-profits in Japan, South Korea and Taiwan. In Japan, traditional varieties are generally cultivated on the basis of heritage and culture, and an array of non-profits are involved in seed provision, domestic production, collection and networking. In South Korea, where interest in heirloom seeds has been growing since the early 2000s, comparable organizations include a research firm, cooperative and civil society network. Relevant non-profits in Taiwan, meanwhile, are at the formative stage. Informal systems are key to maintaining agrobiodiversity, Tomiyoshi concludes, but to operate sustainably they must better integrate their functions and set strategies for collaboration with public institutions.
\end{abstract}

M. Tomiyoshi $(\bowtie)$

Kurume University, Kurume, Japan

e-mail: tomiyoshi_mitsuyuki@kurume-u.ac.jp

(C) The Author(s) 2022

Y. Nishikawa and M. Pimbert (eds.), Seeds for Diversity and Inclusion, https://doi.org/10.1007/978-3-030-89405-4_7 
Keywords Community seed bank (CSB) - Cultural heritage · Farmers' rights $\cdot$ Non-profit organization (NPOs) $\cdot$ Social movement

\subsection{INTRODUCTION}

In the field of seed management research, systems for saving seeds are classified as either formal (established by governments or seed companies) or informal (established by farmers producing or sharing seeds themselves). Various studies have concluded that the latter systems-networks of farmers sharing seeds-play a passive role, merely supplementing the functions of formal systems. However, this is a mistaken view.

Research has revealed the importance of, and diverse roles played by, farmers' seed networks (Coomes et al., 2015). One example of such an heirloom seed management system is the community seed bank (CSB). These organizations (also known as seed libraries or seed savers' networks) are generally expected to function as hubs in the region, promoting an effective means of conserving agricultural biodiversity.

Surveys of the activities of local CSBs are being conducted around the world. The banks have three notable functions: preserving crop genetic resources, promoting access to and use of a region's diverse crops and protecting rights to seeds and food (Vernooy et al., 2014). In Britain and the United States, many surveys of CSBs that function at the domestic level have been published (Curry, 2019; Helicke, 2015). Numerous studies have also examined their role in protecting farmers' rights (Vernooy et al., 2020).

In Japan, it is primarily small and family farmers who grow heirloom varieties. There is limited data on the conservation of heirloom cultivars by such farmers. The Japan Organic Agriculture Association (JOAA), a non-profit organization or NPO, conducted a study of on-farm seed saving by organic farmers in Japan, and found that $58.7 \%$ of such farmers are involved in the practice. Among Japanese farmers as a whole, however, organic farmers represent a very small proportion.

In addition, Mitsuyuki Tomiyoshi et al. (2021) investigated the number of farmers in the Noto Peninsula-a disadvantaged rural area of Japan with many small-scale farmers - to gauge the prevalence of seed 
collection. Among all locals growing some kind of crop, including fulltime, part-time and subsistence farmers, some $21 \%$ were found to engage in the practice.

In Korea and Taiwan, numbers of smallholders that play a central role in the conservation and use of heirloom cultivars is declining because of demographic ageing. This is problematic, given the need to forge a relevant management system that involves a number of organizations. However, only a limited number of studies about seed conservation activities have been carried out in East Asia.

In this chapter, we will analyse the results of surveys about Japan, Korea and Taiwan to determine the roles CSBs and other NPOs play in East Asian seed conservation. Using this analysis, we will discuss the state of the practice in East Asia and compare functions of seed management by CSBs with those proposed by Ronnie Vernooy et al. (2014). We will also extend that framework to make it more universally applicable.

\subsection{FunCtion of Non-Profits in Seed Conservation}

NPOs are generally involved in the management of genetic resources through self seed saving, seed collection and storage, seed provision, food processing and sale and networking. As shown in Table 7.1, each of these activities has been carried out by a range of entities. NPOs, on the other hand, cover many of the activities simultaneously.

Table 7.1 The activities of entities involved in seed conservation and management

\begin{tabular}{|c|c|c|}
\hline Function & Activities & Existing entities \\
\hline Home seed production & $\begin{array}{l}\text { Actively cultivate and produce } \\
\text { seeds }\end{array}$ & Farmers \\
\hline $\begin{array}{l}\text { Seed collection and } \\
\text { conservation }\end{array}$ & $\begin{array}{l}\text { Collect and store varieties that } \\
\text { are disappearing from the area }\end{array}$ & Gene banks/universities \\
\hline Seed provision & Sell seed as a business & Seedling sellers \\
\hline Food processing and sale & $\begin{array}{l}\text { Process/sell harvested produce as } \\
\text { local specialty products }\end{array}$ & Food businesses, etc. \\
\hline Networking & Link various organizations & NPOs, etc. \\
\hline
\end{tabular}




\subsection{Seed-Conservation Non-Profits in Japan}

Fact-finding surveys were conducted focusing on four NPOs involved in the conservation and use of heirloom cultivars: the JOAA (registered under Japan's NPO Act; Kiyosumi no Mura (also NPO-registered); the Hiroshima Prefecture Agriculture and Forestry Promotion Centre Agriculture Seedbank, or Hiroshima Seedbank (a general incorporated foundation); and the Hyogo Heirloom Cultivar Conservation Association, or HCA (an informal civil organization not registered as an NPO).

Based on the survey of these bodies, and the results of the five categories in which they operate, a number of observations were made (see Table 7.2).

\subsubsection{Home Seed Production}

In each of the four organizations surveyed, association members (or staff) cultivated and produced the seeds of heirloom cultivars. In the case of Kiyosumi no Mura, approximately 150 cultivars are conserved on the farm. The JOAA and the HCA had implemented indirect frameworks for organizing home seed production. However, this was not done at an organizational level, but by members individually.

Table 7.2 A comparison of the conservation and use of heirloom cultivars by non-profits and other entities in Japan

\begin{tabular}{|c|c|c|c|c|}
\hline Function & $J O A A$ & $\begin{array}{l}\text { Kiyosumi no } \\
\text { Mura }\end{array}$ & $\begin{array}{l}\text { Hiroshima } \\
\text { Seedbank }\end{array}$ & $H C A$ \\
\hline $\begin{array}{l}\text { Home seed } \\
\text { production }\end{array}$ & $\begin{array}{l}\text { Indirectly } \\
\text { engaged }\end{array}$ & $\begin{array}{l}\text { Directly } \\
\text { engaged }\end{array}$ & Directly engaged & $\begin{array}{l}\text { Indirectly } \\
\text { engaged }\end{array}$ \\
\hline $\begin{array}{l}\text { Seed collection } \\
\text { and conservation }\end{array}$ & $\begin{array}{l}\text { Directly } \\
\text { engaged }\end{array}$ & $\begin{array}{l}\text { Directly } \\
\text { engaged }\end{array}$ & $\begin{array}{l}\text { Systematically } \\
\text { engaged }\end{array}$ & $\begin{array}{l}\text { Directly } \\
\text { engaged }\end{array}$ \\
\hline Seed provision & $\begin{array}{l}\text { Indirectly } \\
\text { engaged }\end{array}$ & $\begin{array}{l}\text { Indirectly } \\
\text { engaged }^{* *}\end{array}$ & $\begin{array}{l}\text { Seed loan } \\
\text { programme }\end{array}$ & $\mathrm{N} / \mathrm{A}$ \\
\hline $\begin{array}{l}\text { Food processing } \\
\text { and sale }\end{array}$ & $\mathrm{N} / \mathrm{A}$ & $\begin{array}{l}\text { Served in } \\
\text { farmers' } \\
\text { restaurant }\end{array}$ & $\mathrm{N} / \mathrm{A}$ & $\mathrm{N} / \mathrm{A}$ \\
\hline Networking & Nationwide & Local & $\mathrm{N} / \mathrm{A}$ & Prefecture-wide \\
\hline
\end{tabular}

${ }^{*}$ Indicates the activities of closely related organizations/individuals

${ }^{* *}$ Including distribution at no charge and seed exchange groups 


\subsubsection{Seed Collection and Conservation}

Hiroshima Seedbank collects heirloom cultivars throughout the prefecture. Approximately 18,000 samples, including seeds and seedlings from outside the prefecture and from Japanese universities, are collected. (This seems a challenging task for a single prefecture, given that the NARO Genebank, a government agency, stores 248,000 samples.)

Rather than collecting heirloom cultivars as an organization, the JOAA mainly stores seeds and seedlings exchanged among its members. However, as in the case of similar organizations in other countries, it is possible that if seed swaps and other activities are held, farmers will come and offer seeds of crops they can no longer cultivate themselves. That would contribute significantly to cultivar conservation.

The HCA has embarked on a project to find heirloom cultivars grown on a small scale in various parts of Hyogo Prefecture. Rather than storing the seeds of the various varieties it finds, the association collects information about the farmers holding them and makes this information available to its members to encourage sustainable cultivation of the cultivars within the prefecture.

\subsubsection{Seed Provision}

The JOAA has plans to establish a seed and seedling sales division. But because of the restrictions in Japan's Plant Variety Protection and Seed Act (revised and approved in 2020) and the costs associated with selling such products, it would be difficult for an NPO to engage in it as a business.

\subsubsection{Food Processing and Sale}

None of the organizations surveyed was involved in food processing or selling (including the sale of agricultural produce), since such enterprises generally involve profit. However, Kiyosumi no Mura has established a system where all agricultural produce grown by members of a related village farm cooperative is bought by the farmers' restaurants managed by the leader of that NPO. 


\subsubsection{Networking}

The JOAA has a nationwide network and promotes crop diversity by enabling members to share seeds and information. Kiyosumi no Mura mainly strengthens existing farmers' networks by cooperating with village authorities in Nara Prefecture. However, many artists, students and researchers from outside the prefecture participate in its activities, so it appears that the NPO also acts as a platform for connecting villages with stakeholders outside the locality. Painters, for example, have created calendars with pictures of traditional vegetables, and seed-themed events are sometimes held in the restaurants. HCA promotes the conservation and consumption of heirloom cultivars by connecting farmers, gardeners and consumers, mainly in Hyogo Prefecture.

\subsection{Non-Profits and Similar Organizations in South Korea}

The roles of South Korean organizations involved in the management of traditional cultivars, as indicated by a survey of three bodies operating in Korea, are presented in Table 7.3.

Each of the three organizations is engaged in home seed production aimed at cultivar renewal. Heuksalim, a joint stock company and related private research institute, conducts cultivation and seed production at its laboratory. Shinlim, an agricultural cooperative, preserves seed lines in its

Table 7.3 A comparison of private South Korean organizations and agricultural cooperatives involved in seed conservation

\begin{tabular}{|c|c|c|c|}
\hline Function & Heuksalim & $\begin{array}{l}\text { Shinlim agricultural } \\
\text { cooperatives }\end{array}$ & Seedream \\
\hline $\begin{array}{l}\text { Home seed } \\
\text { production }\end{array}$ & Directly engaged & Directly engaged & Directly engaged \\
\hline $\begin{array}{l}\text { Seed collection and } \\
\text { conservation }\end{array}$ & Directly engaged & Directly engaged & Directly engaged \\
\hline Seed provision & Indirectly engaged* & Indirectly engaged ${ }^{*}$ & Indirectly engaged ${ }^{*}$ \\
\hline $\begin{array}{l}\text { Food processing and } \\
\text { sale }\end{array}$ & Directly engaged & Directly engaged & None \\
\hline Networking & Directly engaged & Regional & National scale ${ }^{* *}$ \\
\hline
\end{tabular}

\footnotetext{
${ }^{*}$ Including distribution of seed gratis

${ }^{* *}$ Network centred around Seedream founder and government research officer An Wan-Shok
} 
fields. Seedream explores traditional varieties and also provides training for seed savers. Each of the organizations managed over 1000 strains.

The three bodies are on the whole larger than comparable NPOs and other organizations in Japan, a difference that may be partly down to their food processing and sales enterprises (described in Sect. 7.6). Because their main businesses are dealing primarily in traditional cultivars, it is possible for them, especially Heuksalim and Shinlim, to engage in the conservation of traditional cultivars - an expensive operation for a nonprofit. Those two organizations launched in response to two big shocks that hit the South Korean economy within the past several decades: an intervention by the International Monetary Fund in 1997, and a Free Trade Agreement with the United States in 2008. Both of these initiatives had negative effects on the country's food sovereignty.

All three of the surveyed organizations are also engaged in seed collection and storage. At Seedream, seeds are managed in small storage buildings beside fields - a method also used by Japanese NPOs. However, we think that securing funds to continuously manage such a system is a major challenge if the activity is to continue.

Heuksalim's research centre provides cereal seed at no cost to its contract growers. Shinlim does something similar. However, since Seedream does not independently sell seeds of traditional cultivars, its function as a seed provider is limited. Overall, seed provision in South Korea is very different from that in Japan, where there are many small-scale seed and seedling retailers (such as Noguchi Seeds) that sell traditional, open-pollinated cultivars.

Heuksalim and Shinlim are also both engaged in food processing and selling, including the sale of agricultural produce. Both have commercialized operations by branding traditional varieties, which are not suitable for distribution as Fl hybrids are; and both provide vegetable delivery services to members. Japanese NPOs' efforts, by contrast, tend to be limited to conservation and rarely expand into sales and distribution.

Through their efforts to manage traditional cultivars with contract growers and other parties, Heuksalim and Shinlim have created networks. To date, these remain mostly localized. Seedream, however, has members in many regions and acts as a platform linking a wide variety of people. In fact, Seedream has more than 6000 members, making it the biggest network and technical association of the three organizations studied (Kim, 2013). 
Seedream has also established relationships with both governmental and non-governmental organizations through its extensive networks. Seedream's founder, An Wan-Shok, himself has strong connections with many different organizations and groups, and is a key figure in the field of traditional cultivar management. He was the government research officer in charge of the Korea Genebank, in the National Agrobiodiversity Center (NAC) that promoted South Korean agriculture during the time when the government was applying the Green Revolution approach. The South Korean facility also had strong ties with Japan's national gene bank.

However, after meeting leaders of the Korean Peasant Women Association, An Wan-Shok was introduced to the importance of local seed conservation through Indigenous knowledge, especially that held by female elders. He did not explicitly support a food sovereignty movement, but offers his knowledge and network to support the preservation of native seeds by civil society, while keeping strong ties with governmental institutions. We can see this as a case of an integrated endogenous development approach within the sovereignty frame, combined with a rather neutral stance on science and technology in the public sector.

\subsection{Non-Profits in Taiwan}

The survey of NPOs in Taiwan was conducted in tandem with the agronomist Warren Kuo, the foremost authority on the conservation of heirloom cultivars in Taiwan. According to Kuo, only a few farmers in Taiwan produce their own seeds. Although a relatively large number still cultivate local varieties of beans and cucumbers, most farmers buy seeds and seedlings. However, the custom of home seed production is still strong in some Indigenous villages in eastern Taiwan.

\subsubsection{Warren Kuo and His Networks}

In 2011, Warren Kuo held a conference with six Taiwanese NPOs. Subsequently, the NPOs launched workshops and began to teach farmers home seed production methods. This approach echoes participatory plant breeding, but has not been adopted by the Taiwanese government, and remains within the domain of research and farming. 


\subsubsection{Hope Market}

Hope Market is a private organization in Taichung City comprised of more than 30 organic farmers who hold a farmer's market twice a month. In 2011, the organization launched an heirloom seed conservation project.

Hope Market focuses on Formosan and heirloom rice of the indica variety. Although its farmers acquired cultivars from Thailand in the market's first year of its operation, from the second year onwards they purchased local cultivars and selected plants from those. As part of this project, they have formulated a model in which farmers can save their own seeds at home. They also plan to run cultivar exchange workshops.

\subsection{Comparison of THE THREe Countries AND Regions}

We compared the nature of NPOs' activities in three East Asian countries (see Table 7.4), including government institutions and seed companies for reference.

Our findings showed that NPOs in Taiwan are still in the early stages of development, and also that there was no evidence among them of any involvement in collecting and conserving heirloom varieties. Thus, compared with Japanese NPOs and heirloom cultivar conservation societies, Taiwan's are at the formative stage.

However, additional surveys carried out by Warren Kuo revealed that in 2013, NPOs in Taiwan developed a network known as Farmers' Conservation of Seeds. This network spread throughout the country, and is expected to remain active. By contrast, the government has made little effort towards participatory plant breeding, leaving it to researchers and farmers to spearhead such efforts. In Taiwan, university researchers are playing a leading role in such activities.

\subsection{CONCLUSION}

In Japan, South Korea and Taiwan, just a handful of organizations are involved in the social movement against global agribusiness. However, a few of these NPOs are also collaborating with global networks such as Vía Campesina, and their work demonstrates an awareness of farmers' rights. 
Table 7.4 A comparison of genetic resource/heirloom seed conservation efforts in Taiwan, Japan and Korea

\begin{tabular}{|c|c|c|c|}
\hline $\begin{array}{l}\text { Type of } \\
\text { organization }\end{array}$ & Taiwan & Japan & South Korea \\
\hline $\begin{array}{l}\text { Government } \\
\text { institution }\end{array}$ & $\begin{array}{l}\text { Plant genetic resources } \\
\text { in gene banks: } \\
\text { approximately } 80,000 \\
\text { items } \\
\text { - Government has a } \\
\text { passive attitude } \\
\text { regarding } \\
\text { participatory plant } \\
\text { breeding }\end{array}$ & $\begin{array}{l}\text { Plant genetic resources } \\
\text { in gene banks: } \\
\text { approximately } 220,000 \\
\text { items } \\
\text { - Government/local } \\
\text { government support } \\
\text { the conservation of } \\
\text { traditional vegetables }\end{array}$ & $\begin{array}{l}\text { Plant genetic } \\
\text { resources in gene } \\
\text { banks: } \\
\text { approximately } \\
200,000 \text { items }\end{array}$ \\
\hline $\begin{array}{l}\text { Seed/seedling } \\
\text { company }\end{array}$ & $\begin{array}{l}\text { Links with Japanese } \\
\text { seed companies due to } \\
\text { the territory's } \\
\text { suitability as a place } \\
\text { for growing seeds } \\
\text { Small- and } \\
\text { medium-sized seed } \\
\text { companies aiming to } \\
\text { popularize } \\
\text { open-pollinated } \\
\text { varieties and home } \\
\text { seed production }\end{array}$ & $\begin{array}{l}\text { A diminishing number } \\
\text { of small- to } \\
\text { medium-sized seed } \\
\text { companies } \\
\text { Seed companies } \\
\text { specialising in heirloom } \\
\text { seeds exist }\end{array}$ & $\begin{array}{l}\text { Many large-scale } \\
\text { seed companies } \\
\text { bought out by } \\
\text { multinational } \\
\text { corporations } \\
\text { State of small- to } \\
\text { medium-sized } \\
\text { seed companies is } \\
\text { unclear }\end{array}$ \\
\hline NPOs & $\begin{array}{l}\text { Conservation activities } \\
\text { commenced on the } \\
\text { basis of advice from } \\
\text { university researchers } \\
\text { Collection and } \\
\text { conservation } \\
\text { programmes for local } \\
\text { heirloom cultivars } \\
\text { introduced } \\
\text { Nationwide network } \\
\text { launched }\end{array}$ & $\begin{array}{l}\text { National, prefectural } \\
\text { and local organizations } \\
\text { active throughout the } \\
\text { country } \\
\text { Many organizations of } \\
\text { different sizes }\end{array}$ & $\begin{array}{l}\text { Surveys and } \\
\text { collaboration on a } \\
\text { national level by } \\
\text { farmers } \\
\text { organizations } \\
\text { Conservation and } \\
\text { dissemination by } \\
\text { public interest } \\
\text { incorporated } \\
\text { foundations in } \\
\text { collaboration with } \\
\text { companies } \\
\text { Small number of } \\
\text { large-scale } \\
\text { organizations }\end{array}$ \\
\hline
\end{tabular}

Source Author's on-site surveys 
Cases in Japan explicitly show that those involved in seed-saving activities, whether farmers or citizens, continue to cultivate traditional varieties on the basis of heritage and culture, guided by family traditions and culinary rationales. Thus, the motivation there often seems to be a microawareness, allied to locality and kinship, rather than global movements or rights-based approaches. Thus, the greater context for seed cultivation and saving in Japan is a concern to pass on heirloom cultivars and farming culture.

In South Korea, interest in traditional varieties of crops and vegetables has been growing since the early 2000s, and the Korean Women's Peasant Association has been working to develop a movement for food sovereignty. In 2007, Seedream was established through the initiative of civil society activism and Heuksalim (see Sect. 7.4 and Table 7.3). Byeong-Seon Yoon et al. (2013) and Hyo Jeong Kim (2013) have mentioned that women play an important role in the conservation of Indigenous species in South Korea. There is an emphasis on seeds themselves rather than the concept of farmers' rights in collaborations between Seedream, Heuksalim and women farmers; but that does not discount the value of these collaborations in elevating women's position in farming villages and households.

Taiwanese CSBs established and run by NPOs and similar institutions are still in the early stages of development.

In both Japan and South Korea, there are NPOs, agricultural associations and public institutions at the prefectural and municipal levels that are fulfilling the role of CSBs. In many cases, such activities are included in the multifaceted activities of CSBs, described by Ronnie Vernooy et al. (2014) as preserving crop genetic resources and promoting access to and use of a region's diverse crops. However, it is rare for NPOs in these three countries to be attuned to social movements for food sovereignty.

For organizations working as community seed banks to function more reliably and sustainably both in local communities and on a global scale, it is essential to integrate their different roles and functions, and also to establish strategies for co-existence and collaboration among NPOs and public institutions.

Acknowledgements This research was partly funded by the Japan Society for the Promotion of Science (JSPS) KAKENHI (Grant Number 24658194; 25850160; 16K18767; 20K06289). 


\section{REFERENCES}

Coomes, O., McGuire, S., Garine, E., Caillon, S., McKey, D., Demeulenaere, E., et al. (2015). Farmer seed networks make a limited contribution to agriculture? Four common misconceptions. Food Policy, 56, 41-50. https://doi. org/10.1016/j.foodpol.2015.07.008

Curry, H. A. (2019). Gene banks, seed libraries, and vegetable sanctuaries: The cultivation and conservation of heritage vegetables in Britain, 1970-1985. Culture, Agriculture, Food and Environment, 41(2), 87-96. https://doi.org/ $10.1111 /$ cuag. 12239

Helicke, N. A. (2015). Seed exchange networks and food system resilience in the United States. Journal of Environmental Studies and Sciences, 5, 636-649. https://doi.org/10.1007/s13412-015-0346-5

Kim, H. J. (2013, September). Women's indigenous knowledge and food sovereignty: Experiences from KWPA's movement in South Korea. Paper for discussion at the Food Sovereignty: A Critical Dialogue international conference, New Haven, CT. Retrieved July 21, 2021, from https://www.tni.org/ files/download/71_hyojeong_2013_0.pdf

Tomiyoshi, M., Uchiyama, Y., \& Kohsaka, R. (2021). Evaluating plant genetic diversity maintained by local farmers and residents: A comprehensive assessment of continuous vegetable cultivation and seed-saving activities on a regional scale in Japan. The International Journal of Sociology of Agriculture and Food, 26, 2. https://doi.org/10.48416/ijsaf.v26i2.433

Vernooy, R., Sthapit, B., Galluzzi, G., \& Shrestha, P. (2014). The multiple functions and services of community seedbanks. Resources, 3, 636-656. https:// doi.org/10.3390/resources3040636

Vernooy, R., Mulesa, T. H., Gupta, A., Jony, J. A., Koffi, K. E., Mbozi, H., \& Wakkumbure, C. L. K. (2020). The role of community seed banks in achieving farmers' rights. Development in Practice, 30(5), 561-574. https:// doi.org/10.1080/09614524.2020.1727415

Yoon, B.-S., Song, W. K., \& Lee, H. J. (2013). The struggle for food sovereignty in South Korea. Monthly Review, 65(1), 56-62. https://doi.org/10.14452/ MR-065-01-2013-05_5 
Open Access This chapter is licensed under the terms of the Creative Commons Attribution 4.0 International License (http://creativecommons.org/licenses/ by $/ 4.0 /$ ), which permits use, sharing, adaptation, distribution and reproduction in any medium or format, as long as you give appropriate credit to the original author(s) and the source, provide a link to the Creative Commons license and indicate if changes were made.

The images or other third party material in this chapter are included in the chapter's Creative Commons license, unless indicated otherwise in a credit line to the material. If material is not included in the chapter's Creative Commons license and your intended use is not permitted by statutory regulation or exceeds the permitted use, you will need to obtain permission directly from the copyright holder.

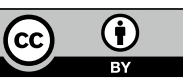

